\title{
Tax Policy, Location Choices and Market Structure
}

Citation for published version (APA):

Pfann, G. A., \& van Kranenburg, H. L. (2003). Tax Policy, Location Choices and Market Structure. Journal of Law \& Economics, 46, 61-83. https://doi.org/10.1086/343780

Document status and date:

Published: 01/01/2003

DOI:

$10.1086 / 343780$

Document Version:

Publisher's PDF, also known as Version of record

\section{Please check the document version of this publication:}

- A submitted manuscript is the version of the article upon submission and before peer-review. There can be important differences between the submitted version and the official published version of record.

People interested in the research are advised to contact the author for the final version of the publication, or visit the DOI to the publisher's website.

- The final author version and the galley proof are versions of the publication after peer review.

- The final published version features the final layout of the paper including the volume, issue and page numbers.

Link to publication

\footnotetext{
General rights rights.

- You may freely distribute the URL identifying the publication in the public portal. please follow below link for the End User Agreement:

www.umlib.nl/taverne-license

Take down policy

If you believe that this document breaches copyright please contact us at:

repository@maastrichtuniversity.nl

providing details and we will investigate your claim.
}

Copyright and moral rights for the publications made accessible in the public portal are retained by the authors and/or other copyright owners and it is a condition of accessing publications that users recognise and abide by the legal requirements associated with these

- Users may download and print one copy of any publication from the public portal for the purpose of private study or research.

- You may not further distribute the material or use it for any profit-making activity or commercial gain

If the publication is distributed under the terms of Article $25 \mathrm{fa}$ of the Dutch Copyright Act, indicated by the "Taverne" license above, 


\title{
TAX POLICY, LOCATION CHOICES, AND MARKET STRUCTURE*
}

\author{
GERARD A. PFANN and HANS VAN KRANENBURG \\ Maastricht University Maastricht University
}

\begin{abstract}
A structural model of entry and fiscal policy is presented. It shows that taxation of variable production costs can increase product prices, lower competition, and reduce the availability of new products in small markets. The model's test is based on a unique nationwide fiscal experiment. We study the effects of the 1869 Stamped Paper Tax Reform Act on the market for daily newspapers in the Netherlands. The econometric analysis uses data on when and where the newspapers existed and were introduced together with demographic census data from 1859 and 1869 . The results confirm the model's predictions and show how taxation affects strategic business location decisions.
\end{abstract}

\section{INTRODUCTION}

Every morning, when you opened the morning newspaper, "cut" was the most common noun, "cut" was the most regular verb. [Sir Malcom Bradbury, Cuts (1987)]

$\mathbf{T}$ HIS paper shows that fiscal policy has a direct impact on business location decisions of firms, production, competition, and the structure of markets. Taxes levied on the costs of production lower the profitability of firms, discourage markets from growing, dampen competition, and suppress the development of new industries. Usually we do not observe cost-reducing shocks, let alone their exact timing. This is why quantifying the effects of

* Research Director, Institute for the Study of Labor (IZA), Bonn, and Professor of Econometrics and Organization, Business Investment Research Center (BIRC), Maastricht University, and Centre for Economic Policy Research; and Assistant Professor, Department of Strategy, Maastricht University, and BIRC. We gratefully acknowledge Joan Hemels for his willingness to share with us his profound and encyclopedic knowledge about the Dutch daily newspapers in general and about the "Dagbladzegel" in particular. We thank Dennis Carlton, Paul Geroski, Boyan Jovanovic, Marc van Wegberg, and a referee for helpful and stimulating comments. We are grateful to Margard Ody for kindly editing the paper's final draft. Gerard Pfann thanks the University of Chicago Irving B. Harris Graduate School of Public Policy Studies for its hospitality and the N.W.O.-PIONIER program of the Netherlands Foundation for Scientific Research for providing financial support. All errors are ours.

Journal of Law and Economics, vol. XLVI (April 2003)]

(C) 2003 by The University of Chicago. All rights reserved. 0022-2186/2003/4601-0003\$01.50 
taxation on firms' profits and on the organization of markets is uncommon in the structural-empirical literature on public finance and industrial organization. As a result of this lack of information, it has long been thought that fiscal policy and governmental incentive programs did not have a large impact on location choices of firms. ${ }^{1}$ Later results-arguably blurred by severe identification problems - gave at most a vague image of that relationship. ${ }^{2}$

Only quite recently, a ground-breaking study comparing differences in economic activity along borders of states that vary in particular probusiness or antibusiness legislations provided convincing evidence that governmental policy can indeed influence decisions on where firms set up their plants. ${ }^{3}$ Thomas J. Holmes's model of antibusiness versus probusiness states is essentially static, and the empirical study is a cross-section analysis at one point in time. Our paper aims to extend the literature by adding a dynamic dimension to the business location model. We investigate entry decisions and realized location choices in condensed markets aroused by a pregnant change in corporate tax law.

Existing theoretical models of entry and taxation assume either imperfect competition or monopolists' provision of new goods. ${ }^{4}$ Free-entry models relating entry to zero-profits thresholds of equilibrium demand have been developed to study how entry in concentrated markets changes the profitability of firms without the necessity to observe price cost margins of incumbent and entering firms. ${ }^{5}$ Free-entry models are helpful to quantify how costreducing shocks affect profitability as a result of the change in market structure. The model presented in this paper links imperfect-competition models with free-entry models. We study how prices, profits, and entry into

\footnotetext{
${ }^{1}$ Dennis W. Carlton, The Location and Employment Choices of New Firms: An Econometric Model with Discrete and Continuous Endogenous Variables, 65 Rev. Econ. \& Stat. 440 (1983), simultaneously modeled the decisions of businessmen about where to locate their plants and of state planners about how to best attract new employment to their state.

${ }^{2}$ See Michael Wasylenko, Empirical Evidence on Interregional Business Location Decisions and the Role of Fiscal Incentives in Economic Development, in Industry Location and Public Policy 13 (Henry H. Herzog, Jr., \& Alan M. Schlottmann eds. 1991), for an overview of the literature until the late eighties.

${ }^{3}$ Thomas J. Holmes, The Effect of State Policies on the Location of Manufacturing: Evidence from State Borders, 106 J. Pol. Econ. 667 (1998), finds that there is a large, abrupt increase in business activity when one crosses a state border from a state that does not have a rightto-work law into a state that does. Thomas J. Holmes, Scale of Local Production and City Size, 89 Am. Econ. Rev. Pap. \& Proc. 317 (1999), argues that the equilibrium output of any particular locally produced differentiated product depends on the local population size.

${ }^{4}$ Models of imperfect competition were developed in Jesus K. Seade, On the Effects of Entry, 48 Econometrica 479 (1980); and Timothy J. Besley, Commodity Taxation and Imperfect Competition: A Note on the Effects of Entry, 40 J. Pub. Econ. 359 (1989); the model of monopolists' provision of new goods is based on Paul M. Romer, New Goods, Old Theory, and the Welfare Costs of Trade Restrictions, 43 J. Dev. Econ. 5 (1994).

${ }^{5}$ See Timothy F. Bresnahan \& Peter C. Reiss, Entry and Competition in Concentrated Markets, 99 J. Pol. Econ. 977 (1991); and Steve Berry, Estimation of a Model of Entry in the Airline Industry, 60 Econometrica 889 (1992).
} 
concentrated markets changed when a tax that increased the variable costs of production was eliminated. The theoretical model predicts effects that are comparable to those predicted by theories of cost-reducing technological shocks: new firms enter, commodity prices fall, more customers are served, and firms' profits increase. ${ }^{6}$ We find that the minimum efficient scale to warrant profitable entry for a monopolist is larger if the tax rate on variable costs of production increases. Given the size of the population, an increase in expected variable profits increases the probability of accommodating manifold firms in the concentrated marketplace.

The predictions generated by the theoretical model are tested using a uniquely identified nationwide fiscal experiment that drastically changed the market structure for daily newspapers in the Netherlands. On July 1, 1869, 21 years after the freedom of press was written into the New Constitution of the Kingdom of the Netherlands, a new constitutional law was implemented that repealed the Stamped Paper Tax (see Figure 1). Tax stamps on paper used for news provision were no longer legally allowed. Their elimination reduced the variable costs of producing newspapers by as much as 50 percent. The expansion that followed immediately after the installation of the 1869 tax repeal was the largest the Dutch market for newspapers experienced during its growth until World War II.

In addition to the information on when and where daily newspapers existed and entered, geographical information and demographic census data from 1859 and 1869 are collected to investigate relevant differentiations among possible entry locations. The econometric analysis shows that publishers in the largest cities, facing sufficient demand to accommodate multiple newspapers, profited most from the change in competitive conduct induced by the abolishment of the tax on paper used for printing news. Most of the localities that were newly chosen to start up a daily newspaper were towns that had a modest population but had grown substantially in the decade preceding the 1869 tax reform. These towns were usually located far away from a province's largest city-usually its capital city-which was usually already served by at least one newspaper.

The paper is organized as follows. Section II presents the historical background of the Stamped Paper Tax and the arguments used against it at the time it was abolished. In Section III, a structural model is presented that describes how entry choices depend on fiscal policy and market structures. Section IV summarizes the information available in the data and presents the results of the econometric analysis. This part of the paper focuses on how changes in profitability explain the way entry occurred and the dominant factors determining the entry choices of single newspapers. Section V concludes.

${ }^{6}$ See Boyan Jovanovic \& Glenn M. MacDonald, The Life Cycle of a Competitive Industry, 102 J. Pol. Econ. 322 (1994). 


\title{
STAATSBLAD
}

VAX HET

\section{KONINGRIJK DER NBDRRLANDEN.}

\author{
(No. 60.) E $\mathrm{T}$ van don 9dem spril 1869, houdende \\ afschaffing van het zogelsegt op de godrulte stulition \\ ex op de advertention in de vienoopopieren.
}

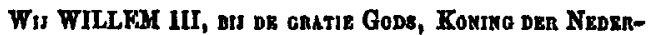
lasidz, Paixe vak Orunse-Nassad, Groot-Hentog yas LUXEMBORG, ENZ., ENZ., ENY.

Allon, die dese rullen xien of hooren lezen, salut! doon to weten:

Alroo $W_{i j}$ in overweging hobben genomen, dat hot noodrakellfk: is hot eegelrogt op do gedrukto stukken en op do adrertentien in do nieur uppopieren af to schaffen:

Zoo is het, dat Wij, den Raad van State gohoord on mot gemoen orerleg dor Staten-Generanl, hebben goedgevonden on reratean, golijk Wij goodvinden on veratean bij deze:

\section{Artikel 1.}

Het regelregt op do gedrukto stakken on op de adrertontien in do nieuwspapieren words met den lantsten dag der maend Junij van het jnar 1869 afgeschaft.

\section{Artikel 4.}

Art. 19 dor wet van 3 Oetober 1819 (Staatbitad $\mathrm{n}^{\circ}$. 47) blijn ran kracht ten asaxion van de zegeliregten op alvertention, goplaatst in bladen, wolke vóbr den Isten Julij 1869 zijo gedrukt 6n uitgegeren.

Lasten on bovelun, dat deze in hot Stantolled zal worden geplaatst, on dat allo Ministeriölo Departomenten, Autoriteiten, Collegion on Ambtenaren, wien zalks asngant, unn do nuallwkeurige uitroering do hand zullen bouden.

Gegeven to 's Gravenhugo, den 9den April 1869.

\section{WILLEM.}

De Mrinister van Finaucien,

VAX DOSSg.

\author{
Uitgogoven ilen tienden April 1869. \\ Do Mrinaster van Justitie, \\ YAX LILAAR.
}

FIgURE 1.-Repeal of the Stamped Paper Tax 
TABLE 1

Stamped Newspaper Tax Revenues per Province in the Netherlands in 1826

\begin{tabular}{llcr}
\hline \hline Province & Largest City & $\begin{array}{c}\text { Number of } \\
\text { Stamped } \\
\text { Papers }(\times 1,000)\end{array}$ & $\begin{array}{r}\text { Stamped Paper } \\
\text { Tax Revenues } \\
(\times 1,000 \text { Dfl })\end{array}$ \\
\hline North Holland & Amsterdam & 2,206 & 44.1 \\
South Holland & Rotterdam & 726 & 14.5 \\
North Brabant & 's Hertogenbosch & 40 & .8 \\
Zeeland & Middelburg & 82 & 1.6 \\
Friesland & Leeuwarden & 286 & 5.7 \\
Utrecht & Utrecht & 60 & 1.2 \\
Gelderland & Arnhem & 137 & 2.7 \\
Overijssel & Zwolle & 37 & .7 \\
Drenthe & Assen & 9 & .2 \\
Groningen & Groningen & 156 & 3.1 \\
Limburg & Maastricht & 42 & .8 \\
\cline { 2 - 4 } Total & & 3,782 & 75.6 \\
\hline
\end{tabular}

NOTE. $-\mathrm{Dfl}=$ Dutch guilders

SourCE. - Joan M. H. J. Hemels, De Pers onder het Juk van een Fiscale Druk 170 (1992).

\section{The 1869 NewsPaper Tax Reform $\mathrm{ACT}^{7}$}

The stamped paper duty was left over from the "timbre extraordinaire pour journaux, gazettes, feuilles périodiques ou papiers-nouvelles" that was part of the French empire's tax laws that had been installed 1 year after the annexation of the Netherlands in 1810. To keep governmental control over the information flowing to citizens, stamped paper was the only legally allowed means for distributing news, advertisements, and other announcements in print among the general public (for example, newspapers). Detailed information on the sums of money flowing into the government's treasury and the number of papers actually stamped is available for every Dutch province in the year 1826 and is listed in Table 1. In that year, the average revenue was 2 cents or .02 Dutch guilders (Dfl) per stamped paper. The "right to stamp" was a taxation that was based on the size of the paper used for printing and publishing. For a piece of paper the size of two palms $\left(1\right.$ palm $\left.=10 \times 10 \mathrm{~cm}^{2}\right)$, no stamp was required. For larger newspapers, the tariffs as of April 1, 1849, are presented in Table 2. The figures on the 1868 financial balance sheet of the Algemeen Handelsblad, an influential daily newspaper, are illustrative of the fact that the stamp tax weighed heavily on exploitation and must have stifled publishers' entrepreneurial initiatives:

${ }^{7}$ Joan M. H. J. Hemels, Het Dagbladzegel in de Rariteitenkamer, 1869-1969 (1969), and Joan M. H. J. Hemels, De Pers onder het Juk van een Fiscale Druk (1992), provide detailed descriptive information on the effects of the repeal of the stamped newspaper tax in 1869 . The historical information presented in Section II of this paper relies to a large extent on these two publications in Dutch. 
TABLE 2

Tariff Rules of Stamped Paper Tax on APRIL 1, 1849

\begin{tabular}{lc}
\hline \hline Size (in palm ${ }^{2}$ ) & Tariff (in Dfl) \\
\hline From 0 to 2 & 0 \\
From 2 to 15 & .01 \\
From 15 to 20 & .015 \\
From 20 to 25 & .02 \\
From 25 to 30 & .025 \\
From 30 to 35 & .03 \\
From 35 to 40 & .035 \\
From 40 to 45 & .04 \\
For every additional 10 & Add .005 \\
$\quad$ (or part of)
\end{tabular}

NoTE. - Dfl $=$ Dutch guilders.

Source. - Joan M. H. J. Hemels, De Pers onder het Juk van een Fiscale Druk 47 (1992).

total expenses were $299,000 \mathrm{Dfl}$, which included the listed amount paid that year to the tax authorities for stamped paper duties of $143,000 \mathrm{Dfl}$, or 48 percent. These numbers show that the per-unit paper tax was proportional to total variable costs and that variable costs were linear in output.

After 1848, when freedom of speech, press, and expression were written into the New Constitution of the Kingdom of the Netherlands, the stamped paper duty represented one of the last remaining obstacles to be removed from the route to economic freedom of the press. On April 17, 1867, an influential group of Dutch intellectuals founded the "Anti-Stamp Duty Alliance." The arguments put forward to persuade the government to abolish the newspaper tax law were based on three grounds:

1. Fundamentally political: A free press is a sine qua non for a parliamentary-constitutionally ruled country. Repeal of the stamped paper duty creates opportunities for new newspapers to be set up and to break down the existing monopolistic structure.

2. Socioeconomic: The imposition of a large levy on a newspaper's gross income is disadvantageous not only for the newspapers themselves: trade and industry suffer losses as well.

3. Cultural: Taxation on the spread of knowledge keeps news beyond the reach of many.

On November 10, 1868, the Nieuwe Rotterdamsche Courant, another widely read daily newspaper, wrote, "Is it not an anomaly that the State spends a fortune on education, while keeping people from decent and inexpensive daily readings through a stamp tax levied upon newspapers?" In fact, all incumbent prominent newspapers were in favor of the abolition of the newspaper tax as well. Publishers regarded the repeal of the stamped paper duty as a means of improving the literacy of Dutch citizens. Being 
responsible for approximately half of the production costs, its repeal would widen the distribution of information they struggled to provide. The Stamped Paper Tax prevented newspaper publishers from using their capital for the improvement and enforcement of their informational powers and contents. Incumbent newspapers actually welcomed more competition. The tax cut was expected to widen and liberalize the market for newspapers. Not only would it enhance competition, it would also increase the availability of information and increase incumbents' opportunities to grow and survive when profits and sales rose as a result of the upward shock in the demand for newspapers in general. Income losses from lower prices due to increased competition were expected to be offset by the increased readership served by those best equipped to face it, in casu, the existing newspapers.

The tax on paper for printing news was officially repealed on July 1, 1869 (Figure 1). The tax cut not only considerably lowered variable production costs but also induced an increase in the number of available newspapers and a decrease in the real aggregate price level. Following the installation of the 1869 tax law, the number of available newspapers increased from 41 to 62 nationwide in the period 1869-71. It is relevant to note that most of the new papers had titles like "general daily newspaper" or "new general daily newspaper." ${ }^{8}$ The market expansion went hand in hand with a 50 percent drop in the aggregate price for newspapers. Such a change in a comparatively short period of time was the largest the market for newspapers has experienced in the entire life cycle of the industry (Figure 2). The reasons for this significant price drop are twofold. First, the Stamped Paper Tax was ad valorem taxation in the sense that the per-unit tax was included in the price for newspapers. It could thus be regarded as a revenue taxation on newspaper providers. Moreover, the change in the market structure after the tax repeal-the increase in competition in big cities and the access of monopolists to smaller towns-also reduced the aggregate price level of newspapers. Thus, entry occurred in two different ways: seven newspapers appeared as monopolists in towns that did not have a newspaper before, while 14 entered cities where other newspapers were already available. Interestingly, in many towns served by one or at most two newspapers, the market structure did not alter. We seek answers to the question, why did entry occur like this? The model presented in the next section provides a theoretical explanation.

\section{A Model of TAXation AND Entry}

The model describes the role of taxation and population on market structures and the profitability of firms. It starts with the analysis of monopolists'

${ }^{8}$ Segregation or religious compartmentalization of the newspaper market in the Netherlands developed much more than 2 decades later, in the late 1890s. 


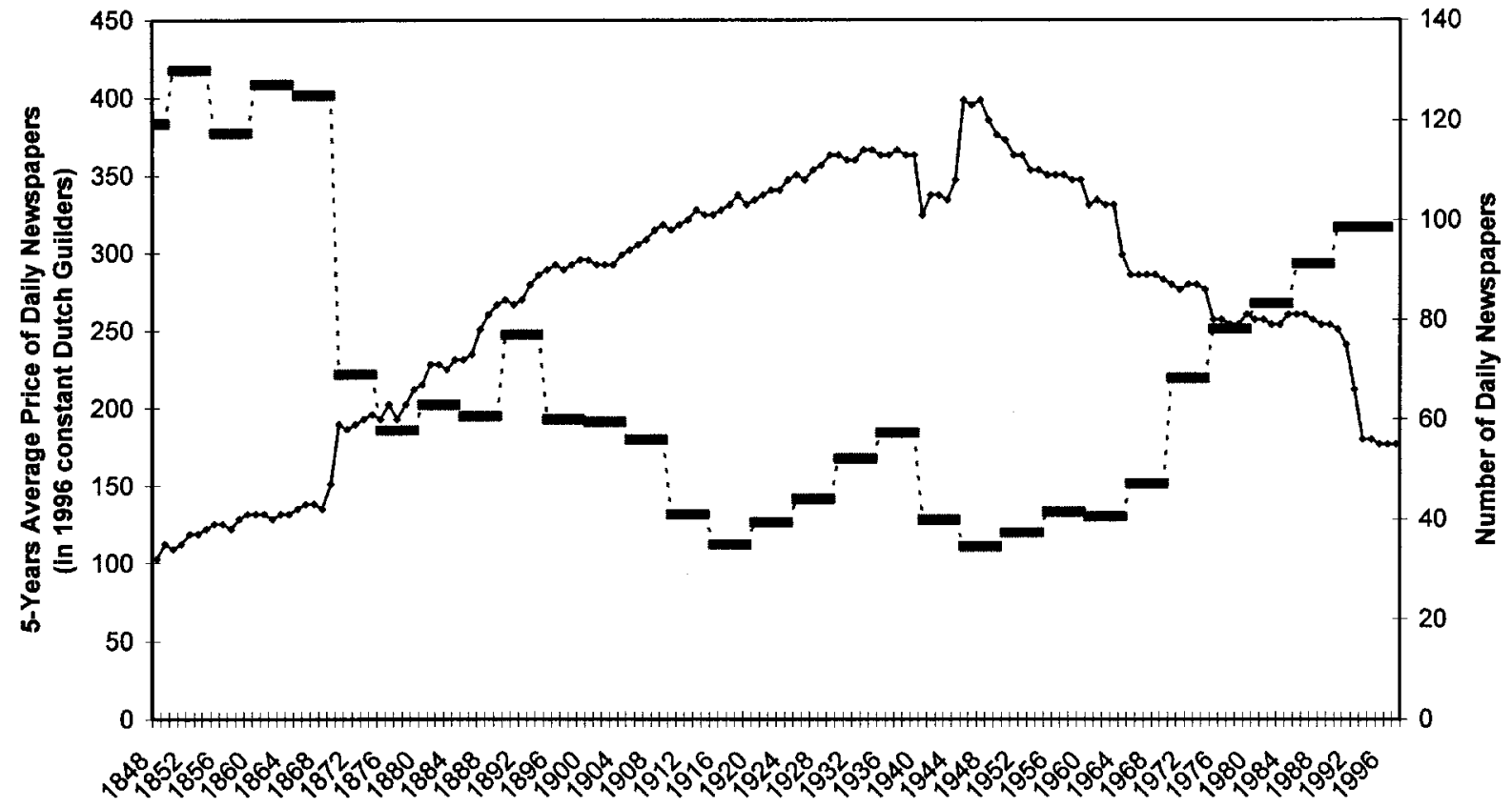

..... Price - Number

FIGURE 2.-The life cycle of daily newspapers in the Netherlands, 1848-1996 
access to geographically isolated markets and is then followed by entry into existing concentrated markets.

\section{A. Entry as a Monopolist}

We investigate the effects of levying taxes on the costs of producing information, on the equilibrium price for information, and on the amount of information provided in each market. ${ }^{9}$

Suppose that a town can produce two types of goods: old goods or new goods. The production of new goods requires information and skilled labor as inputs. A country's gross domestic product consists of the total production from $M+N$ towns. In $M$ towns, old goods are produced, while the $N$ towns produce new goods. Each town can manufacture old goods, but as soon as sufficient information is available, the town changes from producing old goods to producing new goods. The new good, $Y$, is produced using a constant returns-to-scale technology that varies exogenously with each town $i$ 's demographics $\boldsymbol{Z}_{i}$. The necessary inputs to produce $Y_{i}$ are information $X_{i}$ and skilled labor $L_{i}$, which is assumed to be proportional to the town's total population $S_{i}$. In $N_{1}$ towns, the provision of information is in the hands of monopolists. The total production of new goods produced in towns with monopolistic information providers is $Y_{1}$ and yields

$$
Y_{1}=\sum_{i=1}^{N_{1}} Y_{1 i}=\sum_{i=1}^{N_{1}} S_{1}\left(Z_{i}\right)^{1-\alpha} X_{i}^{\alpha}, \quad 0<\alpha<1 .
$$

The setup costs $F_{1}\left(\boldsymbol{W}_{i}\right)$ for a monopolist to provide $X_{i}$ in town $i$ are fixed and depend on a vector of exogenous town-specific characteristics, $\boldsymbol{W}_{i}$. The variable production costs for an additional unit of $X_{i}$ yields $(1+\tau) C_{1}\left(V_{i}, W_{i}\right)$, where $V_{i}$ is a vector of demographic variables affecting the demand for $X_{i}$ and $\tau$ is the rate of taxation levied on the variable costs of production. The tax rate $\tau$ is equal for all towns. Once the firm has entered town $i$, it sets $X_{i}$ and a monopoly price $p_{i}$ to maximize variable profits. The monopolist's decision problem is

$$
\max _{p, X} p_{i}\left(X_{i}\right) X_{i}-(1+\tau) C_{1}\left(V_{i}, W_{i}\right) X_{i},
$$

where

$$
p_{i}\left(X_{i}\right)=\alpha S_{1}\left(\boldsymbol{Z}_{i}\right)^{1-\alpha} X_{i}^{\alpha-1} .
$$

The equilibrium price is equal to

$$
p_{i}^{*}\left(\boldsymbol{V}_{i}, \boldsymbol{W}_{i}, \alpha, \tau\right)=[(1+\tau) / \alpha] C_{1}\left(\boldsymbol{V}_{i}, \boldsymbol{W}_{i}\right),
$$

\footnotetext{
${ }^{9}$ This part of the model is closely related to Romer's, supra note 4, model of new goods.
} 
so a cost-reducing tax shock leads to a lower equilibrium price level, or $\delta p_{i}^{*} / \delta \tau>0$.

The equilibrium provision of information is

$$
X_{i}^{*}\left(\boldsymbol{V}_{i}, \boldsymbol{W}_{i}, \boldsymbol{Z}_{i}, \alpha, \tau\right)=\left[\left(1+\tau / \alpha^{2}\right) C_{1}\left(\boldsymbol{V}_{i}, \boldsymbol{W}_{i}\right)\right]^{-1 /(\alpha-1)} S_{1}\left(\boldsymbol{Z}_{i}\right),
$$

which shows that the equilibrium outcome of cost-reducing tax shocks yields more production of information, or $\delta X_{i}^{*} / \delta \tau>0$. Moreover, we find that in equilibrium $X_{i}^{*}$ is positively correlated with the size of the population in town $i$, or $\delta X_{i}^{*} / \delta S_{1}\left(\boldsymbol{Z}_{i}\right)>0$.

The explicit formulation of the equilibrium $\left(p_{i}^{*} ; X_{i}^{*}\right)$ allows us to derive the effect of taxation on the minimum population size that warrants profitable entry as a monopolist. The total profits of town $i$ 's monopolist are

$$
\begin{aligned}
\Pi_{1 i}= & {\left[p_{i}^{*}\left(\boldsymbol{V}_{i}, \boldsymbol{W}_{i}, \boldsymbol{Z}_{i}, \alpha, \tau\right)-(1+\tau) C_{1}\left(\boldsymbol{V}_{i}, \boldsymbol{W}_{i}\right)\right] } \\
& \times X_{i}^{*}\left(\boldsymbol{V}_{i}, \boldsymbol{W}_{i}, \boldsymbol{Z}_{i}, \alpha, \tau\right)-F_{1}\left(\boldsymbol{W}_{i}\right),
\end{aligned}
$$

or, omitting addenda for computational convenience, we find that

$$
\Pi_{1}=S_{1}(1+\tau)^{[\alpha /(\alpha-1)]} \Psi_{1}-F_{1},
$$

where $\Psi_{1}$ does not depend on $S_{1}$ or on the tax rate $\tau$. From equation (7), it is easy to show that profits are smaller when taxes are larger, or $\delta \Pi_{1} / \delta \tau<$ 0 . A direct comparison of entry thresholds, $\Pi_{1}=0$, under different tax regimes yields

$$
\frac{S_{1}(\tau)}{S_{1}(0)}=(1+\tau)^{[\alpha /(1-\alpha)]},
$$

assuming that the other variables do not change pre- and post-tax. This expression shows that $S_{1}(\tau)>S_{1}(0)$, so the minimum efficient scale that warrants profitable entry for a monopolist increases with the tax rate $\tau$ on variable costs of production.

\section{B. Entry into Existing Markets}

In this part of the model, we consider a second local market structure for the production of new goods. Suppose that one market accommodates $n_{1}=1$ firms, while another market has $n_{2}>1$ firms. The total number of markets in the economy with $n_{2}$ firms is equal to $N_{2} \equiv N-N_{1}$. When firms are facing a downward-sloping demand curve and the size of the market increases, market demand rotates outward. ${ }^{10}$

Figure 3 illustrates that although the change in equilibrium price level may be small when the market structure remains unchanged, the difference can

\footnotetext{
${ }^{10}$ The entry threshold methodology used in this part of the model was first presented by Bresnahan \& Reiss, supra note 5. That study also gave a detailed analytical description of the outward rotation effect.
} 


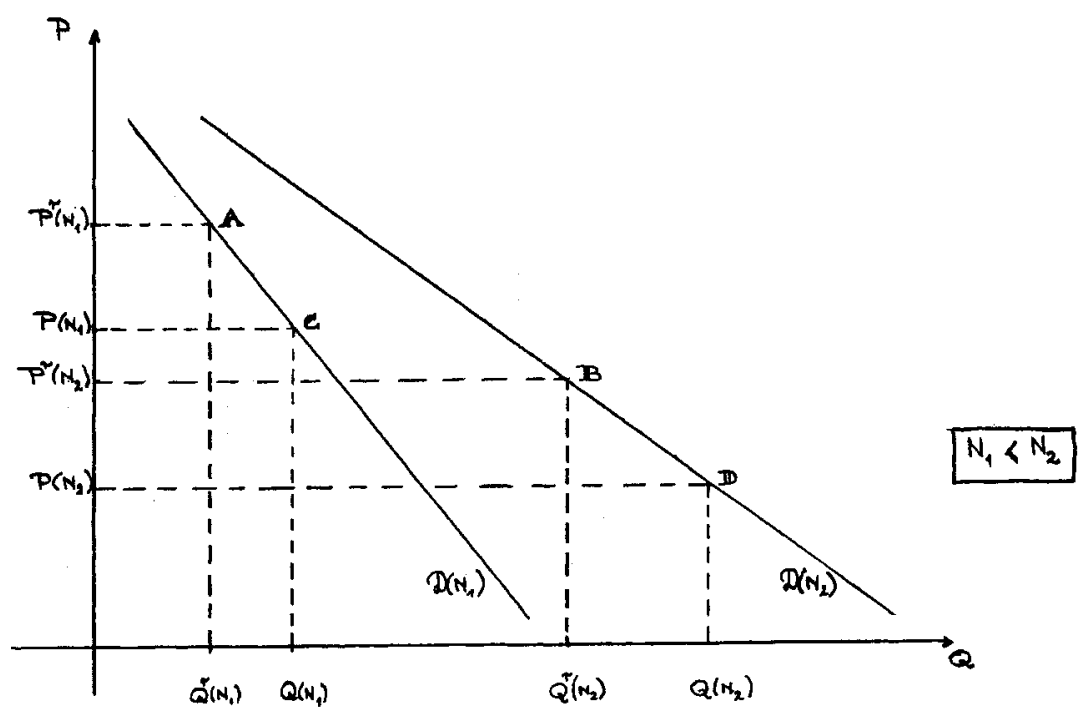

FIGURE 3.-The entry effect of tax changes on prices and quantities

be quite substantial when competition increases. The equilibria in the two markets are $\left\{A:\left[P^{\tau}\left(n_{1}\right) ; Q^{\tau}\left(n_{1}\right)\right]\right\}$ and $\left\{B:\left[P^{\tau}\left(n_{2}\right) ; Q^{\tau}\left(n_{2}\right)\right]\right\}$. A costs-reducing tax shock shifts these to $\left\{C:\left[P\left(n_{1}\right) ; Q\left(n_{1}\right)\right]\right\}$ for the market with $n_{1}$ firms and to $\left\{D:\left[P\left(n_{2}\right) ; Q\left(n_{2}\right)\right]\right\}$ for the market with $n_{2}$ firms. Figure 3 also allows us to study the impact of the tax cut for the smaller local market with $n_{1}$ firms. It can be twofold. First, without entry, there is the pure elasticity effect. The market moves from $A$ to $C$ along the same demand curve $D\left(n_{1}\right)$. Second, the tax cut may induce entry of $n_{2}-n_{1}$ firms. The equilibrium price level then falls from $P\left(n_{1}\right)$ to $P\left(n_{2}\right)$, while the equilibrium output increases with an additional $Q\left(n_{2}\right)-Q\left(n_{1}\right)$. As a result, we find that entry induces prices to fall and that fall is more substantial the more concentrated the market is prior to the shock.

In towns with an oligopoly market structure and with Cournot competition among $n$ identical firms, the average profit for each firm yields

$$
\Pi_{n}=\left(S_{n} / n\right)(1+\tau)^{[\alpha /(\alpha-1)]} \Psi_{n}-F_{n} .
$$

Also, in concentrated markets we find that profits per firm are smaller when taxes are larger, or $\delta \Pi_{n} / \delta \tau<0$. The break-even point for the $n$th firm is $\Pi_{n}=0$. Other things being equal, an increase in variable profits lowers the minimum efficient scale to accommodate $n$ firms, since $S_{n}(\tau)>S_{n}(0)$. When entry occurs, however, and allowing for $F_{n}$ and $\Psi_{n}$ to vary among towns, the overall effect of a tax reduction is difficult to predict. In general, the setup costs are unknown and prices at the town level are not observed. If we also 
allow for the possibility that, given characteristics $\boldsymbol{V}$ and $\boldsymbol{W}$, later entrants have lower variable profits and higher setup costs, so $\Psi_{n}=\Psi_{n+1}$ and $F_{n}=$ $F_{n+1}$, then the model becomes much more difficult to solve analytically.

We shall thus rely on an empirical approach to actually estimate the change in profit margins. An entry threshold is a scale-free unit that contains information about the effect of entry on profit margins. How tax reform changes competition and market structure can be inferred from changes in profit margins between markets with $n+1$ and $n$ firms expressed by the following ratio:

$$
\frac{S_{n} / n}{S_{n+1} / n+1}=\frac{s_{n}}{S_{n+1}}=\frac{F_{n}}{F_{n+1}} \frac{\Psi_{n+1}}{\Psi_{n}} .
$$

The more this ratio deviates from 1, the larger the difference in market power and hence in profit margins between the $n$th and the $(n+1)$ th firm.

\section{An Econometric Analysis of Taxation, Entry Thresholds, AND LOCATION DECISIONS}

In the early years of newspaper publishing, general information was often locally available only through the distribution of newspapers. As mentioned in the Alliance's second and third arguments, the transfer of knowledge and of new information occurred by means of daily newspapers rather than by science books or academic journals. Books were available only through specialized libraries in university towns. Journals as we know them today hardly existed. Table 3 compares demographic data obtained from the 1859 and 1869 censuses with information on when and where newspapers existed and were introduced in the period 1869-71. The census data used in this study are obtained from Statistics Netherlands. ${ }^{11}$

In 1869 , before the tax cut, 42 daily newspapers were published in 31 towns. Two years after the repeal, another 21 newspapers were added. Twothirds of the newcomers entered large cities where other newspapers already existed: Amsterdam $(+5)$, Arnhem (+2), 's Hertogenbosch $(+1)$, The Hague $(+1)$, Groningen $(+1)$, Maastricht $(+1)$, and Rotterdam $(+3)$. The average population of those cities was 85,100 citizens in 1869 . One-third of the new entrants started a new business in provincial towns where no other newspapers were available at that time. The average population of these towns was 12,300 (Den Helder, Deventer, Enkhuizen, Harlingen, Roosendaal, Tilburg, and Winschoten) (Figure 4). The smallest town that added a monopolist newspaper after 1869 was Enkhuizen, with a population of 5,400. In 25 towns that jointly held 28 newspapers at the time of the 1869 tax reform, no new journals

\footnotetext{
${ }^{11}$ The censuses of the period 1795-1971 have been made available by Central Bureau of Statistics Netherlands (CBS) on CDROM. See CBS, Publicaties Volkstellingen, 1795-1971 (1999).
} 
TABLE 3

Changes in Market Structures due to the 1869 Newspaper Tax Reform

\begin{tabular}{|c|c|c|c|}
\hline & \multicolumn{2}{|c|}{ Number of NeWSPapers } & \multirow{2}{*}{$\begin{array}{l}\text { POPUlation: } \\
1869 \text { CENSUS } \\
(\times 1,000)\end{array}$} \\
\hline & $\begin{array}{l}\text { Before the } 1869 \\
\text { Tax Repeal }\end{array}$ & $\begin{array}{c}\text { After the } 1869 \\
\text { Tax Repeal }\end{array}$ & \\
\hline \multicolumn{4}{|c|}{ Newspapers were added: } \\
\hline Amsterdam & 5 & 10 & 264.1 \\
\hline Rotterdam & 1 & 4 & 117.1 \\
\hline The Hague & 1 & 2 & 91.3 \\
\hline Groningen & 2 & 3 & 38.0 \\
\hline Arnhem & 1 & 3 & 32.3 \\
\hline Maastricht & 2 & 3 & 28.5 \\
\hline 's Hertogenbosch & 2 & 3 & 24.4 \\
\hline Total & 14 & 28 & 595.7 \\
\hline \multicolumn{4}{|c|}{ Newspapers first appeared: } \\
\hline Tilburg & 0 & 1 & 21.4 \\
\hline Den Helder & 0 & 1 & 18.5 \\
\hline Deventer & 0 & 1 & 17.8 \\
\hline Harlingen & 0 & 1 & 9.9 \\
\hline Roosendaal & 0 & 1 & 7.6 \\
\hline Winschoten & 0 & 1 & 5.5 \\
\hline Enkhuizen & 0 & 1 & 5.4 \\
\hline Total & 0 & 7 & 86.3 \\
\hline \multicolumn{4}{|c|}{ Number of newspapers $(>0)$ did not change: } \\
\hline Utrecht & 2 & 2 & 60.4 \\
\hline Leiden & 2 & 2 & 39.3 \\
\hline Nijmegen & 2 & 2 & 23.0 \\
\hline Haarlem & 1 & 1 & 31.0 \\
\hline Leeuwarden & 1 & 1 & 26.0 \\
\hline Dordrecht & 1 & 1 & 24.8 \\
\hline Delft & 1 & 1 & 22.0 \\
\hline Zwolle & 1 & 1 & 20.6 \\
\hline Schiedam & 1 & 1 & 19.3 \\
\hline Middelburg & 1 & 1 & 16.6 \\
\hline Gouda & 1 & 1 & 16.0 \\
\hline Breda & 1 & 1 & 15.2 \\
\hline Kampen & 1 & 1 & 14.7 \\
\hline Zutphen & 1 & 1 & 14.6 \\
\hline Amersfoort & 1 & 1 & 13.3 \\
\hline Alkmaar & 1 & 1 & 11.4 \\
\hline Almelo & 1 & 1 & 10.3 \\
\hline Vlissingen & 1 & 1 & 9.6 \\
\hline Roermond & 1 & 1 & 9.2 \\
\hline Tiel & 1 & 1 & 8.1 \\
\hline Zierikzee & 1 & 1 & 7.7 \\
\hline Assen & 1 & 1 & 6.9 \\
\hline Enschede & 1 & 1 & 5.1 \\
\hline Heerlen & 1 & 1 & 5.0 \\
\hline Schagen & 1 & 1 & 2.5 \\
\hline Total & 28 & 28 & 432.7 \\
\hline
\end{tabular}

${ }^{\text {a }}$ Central Bureau of Statistics Netherlands, Publicaties Volkstellingen 1795-1971 (1999). 


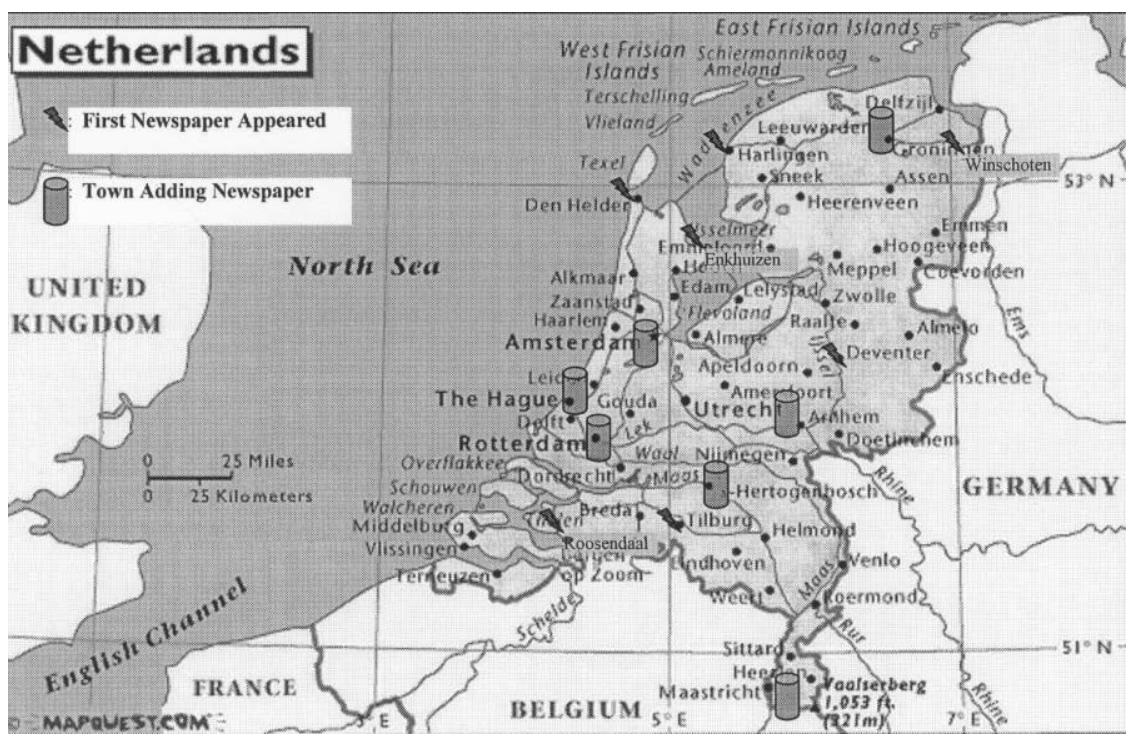

Figure 4.-Map of entry locations and major towns in the Netherlands. SouRCE.-http:// www.mapquest.com (downloaded October 21, 2001).

were added right after the tax repeal. In 1871, the average population per available newspaper had fallen from 24,500 to 17,700 people. The city of 's Hertogenbosch was, with 24,400 inhabitants, the smallest town that added a newspaper to existing ones.

For our empirical analysis, we define the choice set of towns that could have introduced a new journal after the repeal of the Stamped Paper Tax as all existing Dutch towns in 1869 with at least 5,000 citizens. ${ }^{12}$ Figure 4 shows a map of entry locations and all major towns in the Netherlands. It separately identifies the towns where entry occurred. For each town in the data set, the census data include the town's size in thousands of people (Pop1000), the percentage of population growth between 1859 and 1869 (PerGrPop), the average number of people in a single household (PopPerHs), the town's surface area (Area), the number of people per square kilometer (PopArea), and the ratio of unoccupied to occupied houses (EFs). Unfortunately, the census data do not include literacy data or wealth data. We think of the

\footnotetext{
${ }^{12}$ The town of Schagen was smaller than that. Its newspaper was introduced in 1850 shortly after the establishment of the New Constitution. In the analysis of towns that were most likely to add a newspaper after 1869 , we disregard all existing towns with fewer than 5,000 inhabitants in 1869. The reason behind this choice is that it leaves out a large number of small towns where nothing happened as a result of the 1869 tax cut (dropping many uninformative zeros from the probability analysis). The definition of the choice set has the one minor drawback that Schagen is thus excluded from the analysis.
} 
TABLE 4

Demographics of Dutch Towns With and without Newspapers

\begin{tabular}{|c|c|c|c|c|c|c|}
\hline & \multicolumn{2}{|c|}{$\begin{array}{l}\text { TownS WITHOUT } \\
\text { NEWSPAPERS } \\
(\geq 5,000 \text { People) }\end{array}$} & \multicolumn{2}{|c|}{$\begin{array}{c}\text { SINGLE } \\
\text { NEWSPAPER }\end{array}$} & \multicolumn{2}{|c|}{$\begin{array}{c}\text { MUltiPle } \\
\text { NEWSPAPERS }\end{array}$} \\
\hline & Pre-1869 & Post-1869 & Pre-1869 & Post-1869 & Pre-1869 & Post-1869 \\
\hline Number of towns & 45 & 38 & 24 & 28 & 7 & 10 \\
\hline \multicolumn{7}{|l|}{ Population variables: } \\
\hline Pop1000 & $\begin{array}{c}8.21 \\
(3.41)\end{array}$ & $\begin{array}{c}7.45 \\
(1.57)\end{array}$ & $\begin{array}{c}22.8 \\
(26.5)\end{array}$ & $\begin{array}{l}14.1 \\
(7.06)\end{array}$ & $\begin{array}{c}68.3 \\
(87.2)\end{array}$ & $\begin{array}{c}71.9 \\
(74.3)\end{array}$ \\
\hline PerGrPop & $\begin{array}{c}8.02 \\
(3.94)\end{array}$ & $\begin{array}{c}7.32 \\
(2.39)\end{array}$ & $\begin{array}{l}7.37 \\
(6.58)\end{array}$ & $\begin{array}{c}7.60 \\
(6.63)\end{array}$ & $\begin{array}{l}7.37 \\
(2.41)\end{array}$ & $\begin{array}{c}9.84 \\
(5.49)\end{array}$ \\
\hline PopPerHs & $\begin{array}{c}5.50 \\
(1.04)\end{array}$ & $\begin{array}{c}5.52 \\
(1.08)\end{array}$ & $\begin{array}{c}5.83 \\
(1.25)\end{array}$ & $\begin{array}{l}5.55 \\
(.84)\end{array}$ & $\begin{array}{l}7.75 \\
(2.17)\end{array}$ & $\begin{array}{c}7.65 \\
(2.13)\end{array}$ \\
\hline PopArea & $\begin{array}{r}6.20 \\
(14.9)\end{array}$ & $\begin{array}{c}4.05 \\
(5.77)\end{array}$ & $\begin{array}{l}23.8 \\
(27.7)\end{array}$ & $\begin{array}{l}19.7 \\
(26.0)\end{array}$ & $\begin{array}{l}74.2 \\
(82.6)\end{array}$ & $\begin{array}{l}66.7 \\
(72.3)\end{array}$ \\
\hline \multicolumn{7}{|l|}{$\begin{array}{l}\text { Other demographic } \\
\text { variables: }\end{array}$} \\
\hline Area & $\begin{array}{l}3.85 \\
(2.44)\end{array}$ & $\begin{array}{l}3.95 \\
(2.39)\end{array}$ & $\begin{array}{l}2.00 \\
(1.84)\end{array}$ & $\begin{array}{l}2.18 \\
(2.05)\end{array}$ & $\begin{array}{l}1.73 \\
(1.35)\end{array}$ & $\begin{array}{l}2.22 \\
(1.95)\end{array}$ \\
\hline Dist & $\begin{array}{l}.357 \\
(.222)\end{array}$ & $\begin{array}{l}.327 \\
(.206)\end{array}$ & $\begin{array}{l}.247 \\
(.206)\end{array}$ & $\begin{array}{l}.332 \\
(.240)\end{array}$ & $\begin{array}{l}.080 \\
(.144)\end{array}$ & $\begin{array}{l}.082 \\
(.137)\end{array}$ \\
\hline EFs & $\begin{array}{l}6.33 \\
(5.58)\end{array}$ & $\begin{array}{l}6.84 \\
(5.84)\end{array}$ & $\begin{array}{l}10.4 \\
(7.36)\end{array}$ & $\begin{array}{l}8.78 \\
(7.53)\end{array}$ & $\begin{array}{l}9.11 \\
(8.03)\end{array}$ & $\begin{array}{l}9.28 \\
(6.69)\end{array}$ \\
\hline
\end{tabular}

Note. - Standard deviations are in parentheses.

variables PopPerHs and EFs as proxies for a town's wealth and assume that wealthier towns have fewer occupants per household and fewer empty houses. We also measured the distance in kilometers from the town to the largest city of the province (Dist).

Table 4 presents 1869 demographic characteristics of all 76 existing towns with a minimum population of 5,000 citizens. The average population of multiple-newspaper towns before the 1869 tax cut is 3 times as large as that of single-newspaper towns and 5 times as large afterward. While on average the size of single-newspaper towns decreased, for towns that accommodated more than one newspaper it actually went up. Newspapers were added in towns with larger than average population growth during the previous decade and lower population density than existing newspaper towns. Of the two variables that are available to us as proxies of a town's relative wealth, PopPerHs and EFs, the first does not show much variation, while the second one does. New single-newspaper towns had lower average rates of unoccupied houses. They were also located at a greater distance from the provinces' biggest cities.

We can also look at the demographic variation among existing newspapers, newspapers that entered as monopolists, and those entering as competitors in multifirm markets. Table 5 presents the descriptive statistics for the three categories of newspapers. Important differences among them can immediately 
TABLE 5

Descriptive Statistics for Three Types of NewsPapers

\begin{tabular}{|c|c|c|c|c|c|c|}
\hline & \multicolumn{2}{|c|}{$\begin{array}{c}\text { EXISTING } \\
\text { NEWSPAPERS } \\
\text { (41 Firms) }\end{array}$} & \multicolumn{2}{|c|}{$\begin{array}{l}\text { FIRST ENTRY } \\
\text { (7 Firms) }\end{array}$} & \multicolumn{2}{|c|}{$\begin{array}{c}\text { ENTRY INTO } \\
\text { EXISTING MARKET } \\
(14 \text { Firms })\end{array}$} \\
\hline & Mean & SD & Mean & SD & Mean & SD \\
\hline \multicolumn{7}{|c|}{ Firm-specific variables: } \\
\hline YrEntry & 1,820 & 49.7 & 1,870 & .488 & 1,870 & .534 \\
\hline OrderE & 1.36 & .859 & 1 & 0 & 4.64 & 2.79 \\
\hline \multicolumn{7}{|c|}{ Market-specific variables: } \\
\hline Pop1000 & 56.0 & 81.5 & 12.4 & 6.79 & 137.1 & 103.8 \\
\hline PerGrPop & 7.46 & 5.17 & 11.8 & 7.67 & 10.7 & 5.62 \\
\hline PopPerHs & 6.86 & 2.11 & 5.38 & .788 & 8.99 & 2.34 \\
\hline Dist & 17.2 & 19.8 & 51.7 & 25.3 & 1.86 & 6.95 \\
\hline EFs & .093 & .076 & .036 & .028 & .057 & .047 \\
\hline
\end{tabular}

Note. - SD: standard deviation. YrEntry $=$ year of entry; OrderE $=$ order of entry.

be observed. First, monopolist firms entered small towns, while oligopoly firms entered large cities. Second, monopolist firms popped up in faraway towns. Third, both types of entrants chose towns that had seen more than average population growth over the decade preceding the 1869 tax repeal. Fourth, both types of entrants chose towns with a lower percentage of unoccupied houses than existing newspapers. Fifth, entrants in concentrated multifirm markets settled in towns with a large number of people per household.

The 1869 tax reform act can be regarded as a quasi experiment that produced information necessary to investigate the effects of changes in taxation on variable production costs and market structure. We will estimate how the tax cut changed the competition and profitability in markets with one or more newspaper firms. We are seeking answers as to why two-thirds of all new firms entered large cities already served by newspapers, while only one-third entered small towns as monopolists and why no entry occurred in a majority of towns already served by one or two newspapers. A town-specific econometric analysis of the 76 Dutch towns that had 5,000 or more inhabitants in 1869 is presented next.

\section{A. The Econometric Entry Threshold Model}

Before 1869, the number of towns without any newspapers was $M_{\tau}=$ 45 , the number of towns served by a single newspaper was $N_{1 \tau}=24$, and the number of multiple-newspaper towns was $N_{2 \tau}=7$. In the 2 years after the 1869 tax repeal $(\tau=0)$, these numbers changed to $M_{0}=38, N_{10}=$ 28 , and $N_{20}=10$.

We consider the following market structures. When no newspaper is available, profits for newspaper firms are below zero $\left(\Pi_{1 \tau}<0\right)$. If the town has 
one newspaper, we assume that $\Pi_{1 \tau}=0$ and $\Pi_{2 \tau}<0$. For towns with more than one newspaper, we have $\Pi_{2 \tau} \geq 0$. Lacking observations on profits, we assume that all firms in one town experience the same profit and write the total profits averaged over all towns with $J$ firms net of taxes as follows:

$$
\Pi_{J_{\tau}}=\alpha_{\tau} S_{J \tau} \Psi_{J \tau}-J F_{J \tau}+\varepsilon_{J \tau}, \quad J=0,1,2,
$$

where $\alpha_{\tau} \equiv(1+\tau)^{[\alpha /(\alpha-1)]}, F_{J}$ represents the setup costs per firm for towns accommodating $J$ firms, and $\varepsilon_{J}$ is a normally distributed unobserved random error. Equation (11) allows us to write down an ordered-probability model of newspaper provision in Dutch towns before $(\tau>0)$ and after $(\tau=0)$ the repeal of the Stamped Paper Tax. For towns without newspapers we have

$$
\operatorname{Pr}\left(\Pi_{1 \tau}<0\right)=1-\Phi\left(\alpha_{\tau} \Psi_{1 \tau} S_{1 \tau}-F_{1 \tau}\right),
$$

for towns with one newspaper, we have

$$
\operatorname{Pr}\left(\Pi_{1 \tau} \geq 0, \Pi_{2 \tau}<0\right)=\Phi\left(\alpha_{\tau} \Psi_{1 \tau} S_{1 \tau}-F_{1 \tau}\right)-\Phi\left(\alpha_{\tau} \Psi_{2 \tau} S_{2 \tau}-2 F_{2 \tau}\right),
$$

and for towns with two or more newspapers, we have

$$
\operatorname{Pr}\left(\Pi_{2 \tau} \geq 0\right)=\Phi\left(\alpha_{\tau} \Psi_{2 \tau} S_{2 \tau}-2 F_{2 \tau}\right),
$$

where $\Phi($.$) is the cumulative standard normal distribution function,$ $\alpha_{\tau} \Psi_{1 \tau} S_{1 \tau}=F_{1 \tau}$ is the break-even point for monopoly entry, and $\alpha_{\tau} \Psi_{2 \tau} S_{2 \tau}=$ $2 F_{2 \tau}$ is the break-even point for duopoly entry.

The econometric model is specified in the following way:

$$
\begin{gathered}
\alpha_{\tau} \Psi_{1 \tau} S_{1 \tau}=\alpha_{\tau}\left(\text { Pop } 1,000+\delta_{\tau} \text { PerGrPop }+\beta_{1 \tau} \text { Dist }_{1},\right. \\
F_{1 \tau}=\psi_{1 \tau}+\gamma_{1 \tau} \mathrm{EFs}_{1}
\end{gathered}
$$

and

$$
\begin{gathered}
\alpha_{\tau} \Psi_{2 \tau} S_{2 \tau}=\alpha_{\tau}\left(\text { Pop } 1,000+\delta_{\tau} \text { PerGrPop }+\beta_{2 \tau} \text { Dist }_{2},\right. \\
2 F_{2 \tau}=\psi_{2 \tau}+\gamma_{2 \tau} \mathrm{EFs}_{2} .
\end{gathered}
$$

Each town's net present value of revenues is estimated as the linear combination of total population in thousands of inhabitants (Pop1000) and the growth of the population between 1859 and 1869 (PerGrPop). The variable profits of a monopolist are proxied by the covariate Dist $_{1}$, which measures the distance (in $100 \mathrm{~s} \mathrm{~km}$ ) to the province's largest town for all cities that do not accommodate more than one newspaper; the variable profits of a town that accommodates more than one newspaper are proxied by the covariate Dist $_{2}$, which measures the distance (in $100 \mathrm{~s} \mathrm{~km}$ ) to the province's largest town for all cities that do not accommodate one newspaper. Theory predicts a positive effect of profits on the size of the population $\left(\alpha_{\tau}>0\right)$. Given that fixed costs of entry are nonzero, we expect that larger population growth 
rates reduce the time firms spend waiting for entry. ${ }^{13}$ The higher the growth rate of the population, the more likely it is that entry is observed in a concentrated market $\left(\delta_{\tau}<0\right)$. Entry into monopoly markets is predicted to generate a drop in variable profits, so that $\beta_{1 \tau}>\beta_{2 \tau}$.

Setup costs for a monopolist are approximated by the covariate $\mathrm{EFs}_{1}$ that contains the ratio of unoccupied to occupied houses for all cities that do not accommodate more than one newspaper. The term $\mathrm{EFs}_{1}$ is considered to capture, at least in part, possible wealth differences among towns. Wealthier towns have fewer unoccupied houses and thus a lower $\mathrm{EFs}_{1}$ ratio. In wealthier towns, the same setup costs for first entrants form a lesser entry barrier when the expected revenues are higher. Advertising expenditures, for example, necessary to obtain a particular market size are sunk setup costs. When the public purchasing power is higher and more people are able to buy the new good, advertising costs to achieve a given market size can be lower. Setup costs are thus inversely related to a town's wealth. If the ratio of unoccupied to occupied housing is high in comparison with other towns, that town is thought to be less wealthy. Its setup costs are higher; it takes longer to earn back sunk investments since profits are lower. The null hypothesis of this test would then be that the probability that profits would be positive is lower, or $\gamma_{1 \tau}>0$. Changes in setup costs in markets with more than one newspaper are captured by the variable $\mathrm{EFs}_{2}$, which contains the ratio of unoccupied to occupied houses for all cities that do not accommodate one newspaper. If setup costs are higher when markets are more concentrated, then $\gamma_{1 \tau}>\gamma_{2 \tau}$.

Table 6 presents the estimation results of the ordered entry probabilities. Despite the model's scarce parameterization, it predicts the percentages of firms in each category well. In equation (1), we assumed a constant returnsto-scale technology of the production of new goods. The assumption itself is difficult to test, but if it is correct then we can identify the technology parameter $\alpha$ from the fact that

$$
\hat{\alpha}=\frac{\Delta}{1+\Delta}, \quad \text { with } \Delta \equiv \frac{\log \left(\hat{\alpha}_{0} / \hat{\alpha}_{\tau}\right)}{\log (1+\tau)} .
$$

The elimination of tax stamps on paper used for news provision reduced the variable costs of production by approximately 50 percent. ${ }^{14}$ Before the tax repeal we thus have $\tau=1$, whereas after the tax change, $\tau=0$. Table 6 shows that $\hat{\alpha}_{\tau}=.024$ and $\hat{\alpha}_{0}=.243$. We thus estimate $\hat{\alpha}=.771$ (standard error $=.258$ ), given $\tau=1$. This result suggests that the production tech-

\footnotetext{
${ }^{13}$ Avinash K. Dixit, Entry and Exit Decisions under Uncertainty, 97 J. Pol. Econ. 620 (1989), models entry and exit decisions under uncertainty and shows that under fixed-costs regimes the option value associated with the irreversibility of spending these costs can lead to an optimal regime of waiting to invest.

${ }^{14}$ See Hemels, Het Dagbladzegel in de Rariteitenkamer, supra note 7; Hemels, De Pers onder het Juk van een Fiscale Druk, supra note 7.
} 
TABLE 6

Ordered Entry Probabilities before and after the 1869 Tax Reform

\begin{tabular}{|c|c|c|c|c|}
\hline & \multicolumn{2}{|c|}{ PRE-1869 TAX REFORM } & \multicolumn{2}{|c|}{ Post-1869 TAx Reform } \\
\hline & Estimates & $\begin{array}{l}\text { Standard } \\
\text { Error }\end{array}$ & Estimates & $\begin{array}{l}\text { Standard } \\
\text { Error }\end{array}$ \\
\hline \multicolumn{5}{|l|}{ Variables: } \\
\hline Pop1000 $(\alpha)$ & $.024 *$ & .010 & $.243 * *$ & .059 \\
\hline PerGrPop $\left(\alpha^{\delta}\right)$ & -.050 & .038 & $-.104 *$ & .050 \\
\hline $\operatorname{Dist}_{1}\left(\beta_{1}\right)$ & .019 & 1.19 & 2.60 & 1.41 \\
\hline Dist2 $\left(\beta_{2}\right)$ & $-11.3 * *$ & 2.58 & $-13.1 * *$ & 3.82 \\
\hline $\mathrm{EFs}_{1}\left(\gamma_{1}\right)$ & $6.89 *$ & 2.87 & 6.72 & 3.60 \\
\hline $\mathrm{EFs}_{2}\left(\gamma_{2}\right)$ & $-8.78 *$ & 3.97 & -9.26 & 5.01 \\
\hline \multicolumn{5}{|l|}{ Cut points: } \\
\hline$\hat{\psi}_{1}$ & $-1.39 * *$ & .589 & .79 & .84 \\
\hline \multirow[t]{3}{*}{$\psi_{2}$} & .81 & .583 & $5.68 * *$ & 1.58 \\
\hline & & Standard & & Standard \\
\hline & Mean & Deviation & Mean & Deviation \\
\hline \multicolumn{5}{|l|}{ Predicted profits: } \\
\hline$\hat{\Pi}_{0}($ no newspaper $)$ & -4.10 & 2.49 & -2.21 & 2.13 \\
\hline$\hat{\Pi}_{1}$ (single newspaper) & -.520 & .819 & $2.89^{*}$ & 1.53 \\
\hline \multirow[t]{2}{*}{$\hat{\Pi}_{2}$ (multiple newspapers) } & 1.15 & 2.36 & 16.2 & 18.1 \\
\hline & True & Predicted & True & Predicted \\
\hline \multicolumn{5}{|l|}{ Model specification tests: } \\
\hline$\% N_{0}$ (no newspaper) & 59.2 & 59.6 & 50.0 & 49.9 \\
\hline$\% N_{1}$ (single newspaper) & 31.6 & 31.0 & 36.8 & 36.6 \\
\hline$\% N_{2}$ (multiple newspapers) & 9.2 & 9.4 & 13.2 & 13.5 \\
\hline \multicolumn{5}{|l|}{ Likelihood ratio test, } \\
\hline$\chi^{2}$ by equation (5) & \multicolumn{2}{|c|}{$71.5 * * *$} & \multicolumn{2}{|c|}{$115.2 * * *$} \\
\hline Pseudo- $R^{2}$ & .526 & & .773 & \\
\hline
\end{tabular}

NOTE. $-N=76$.

$* p$-value $\in[.01 ; .05]$.

$* * p$-value $<.01$.

$* * *$ *value $=.000$.

nology of new goods used a capital-labor input ratio that is comparable to that of the twentieth century's industrialized economies.

The probability of having a profitable newspaper introduced in a city without a newspaper before 1869 increased from $8 / 45$ to $14 / 45$, or 13.3 percent. Figure 5 shows how the probability of having a profitable monopolist newspaper before the repeal of the Stamped Paper Tax varies with the size of the population. Figure 6 shows the same probability distribution afterward. The dots in both Figures 5 and 6 represent towns that were excluded from newspapers before as well as after the shock. The plus signs are towns that did not have a newspaper before the tax shock but saw entry of a monopolist news provider as a result of the change in the tax law. Comparing Figures 5 and 6 reveals how fiscal policy can contribute to potential market expansion and how the decrease in minimum efficient scale broadened the availability of newspapers. 


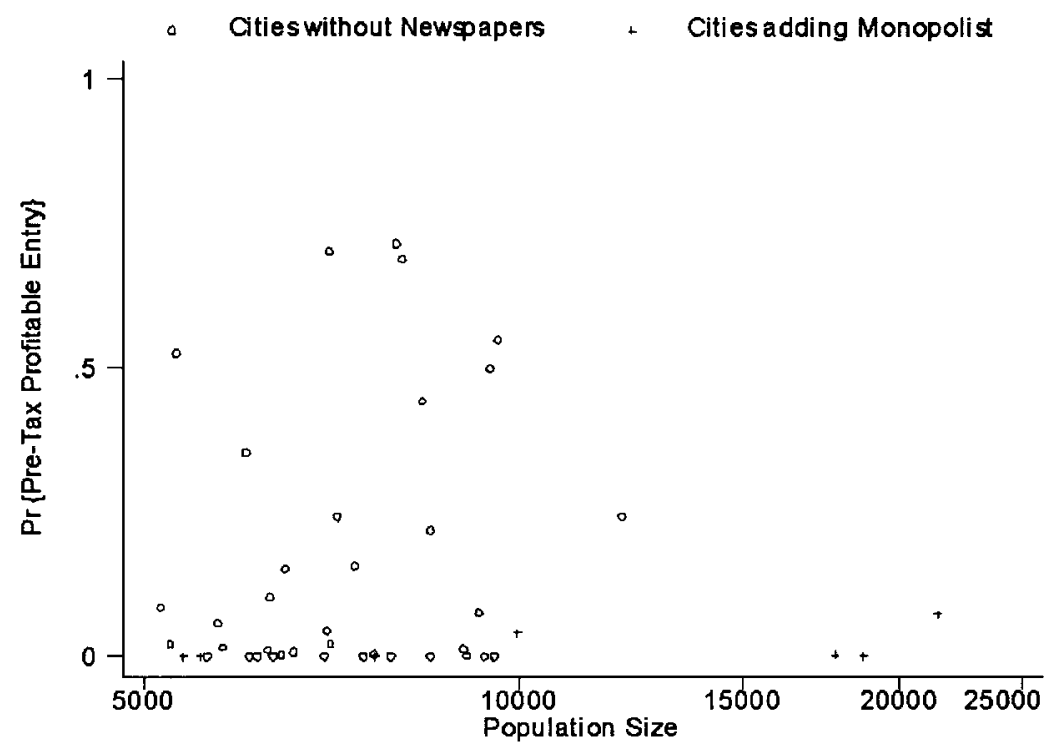

FIGURE 5.-Pre-1869 probability of a profitable single-newspaper entry

The estimated averages of the predicted profits, $\hat{\Pi}_{J}$, suggest a substantial increase of profitability in all sectors after the 1869 tax reform. That $\hat{\psi}_{1}<$ 0 before the repeal is evidence of the fact that preceding the 1869 tax law many of the existing monopolist newspapers were performing unprofitably, possibly because they received subsidies, as they were the officialcontrolled-information platforms of the local governments. These subsidies were discontinued after the tax repeal to balance budgets. The parameter estimates are also in accordance with the theoretical predictions. Interestingly, we find that monopolies were not likely to be found in the neighborhood of the provinces' largest cities. Setup costs are found to be inversely related to the concentration of the market $\left(\hat{\gamma}_{1 \tau}>\hat{\gamma}_{2 \tau}\right)$. And indeed, before as well as after the repeal, wealthier towns had lower setup costs $\left(\hat{\gamma}_{2 \tau}<0\right)$.

Given the distance from the nearest large city, the choice of the city in which to set up new businesses depends on the city's recent growth in population. The fact that the towns chosen had the largest population growth shows that the rationality of the newspaper entrepreneurs in the nineteenth century was no different from what it is today. This has clear policy implications for local governments. If the most thriving towns-those towns that people choose to live in - have the highest probability of being chosen as the most profitable business locations, then not only fiscal incentives matter for business location choices. In addition, governmental policies aimed at 


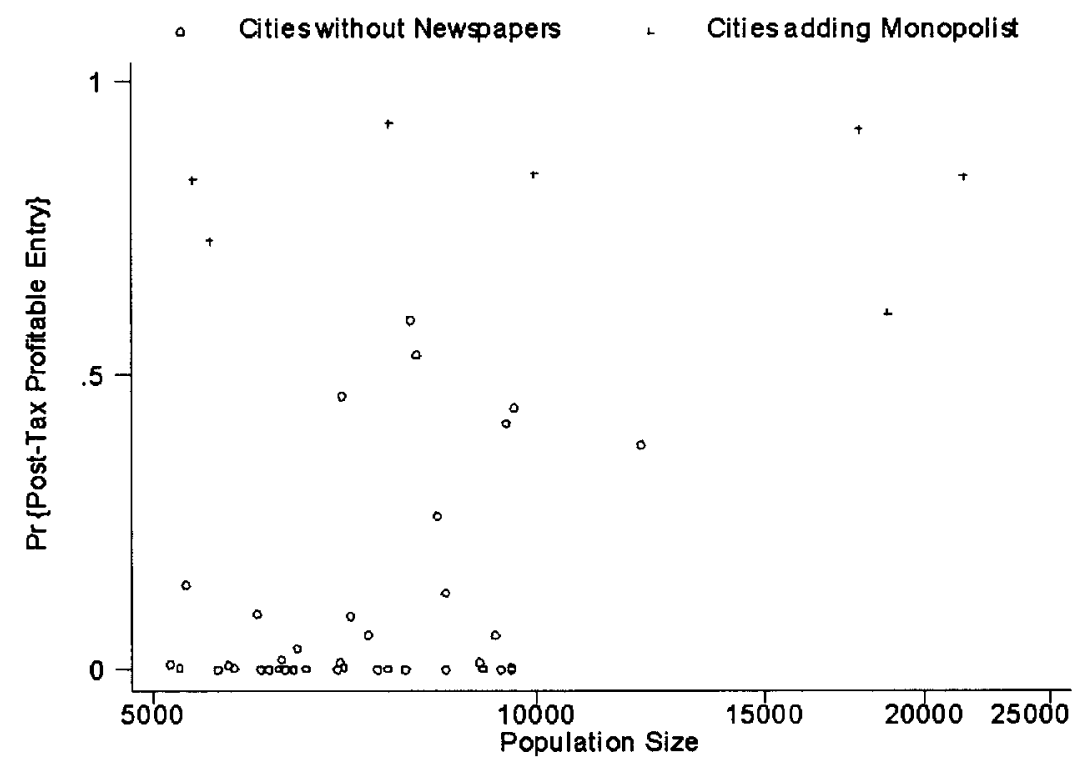

FIGURE 6.-Post-1869 probability of a profitable single-newspaper entry

making a town attractive to live in adds to its future economic prosperity as well.

\section{B. The Effect of the 1869 Tax Repeal on Competition and Market Structure}

The results from Table 6 allow us to compute the change in competition between different market structures. The threshold population sizes for singleand multiple-firm markets are computed as follows:

$$
\tilde{S}_{1 \tau}=\left(\hat{\psi}_{1 \tau}-\hat{\alpha}_{\tau} \hat{\delta}_{\tau} \overline{\operatorname{PerGrPop}}_{\tau}-\hat{\beta}_{1 \tau} \overline{\operatorname{Dist}}_{1 \tau}+\hat{\gamma}_{1 \tau} \overline{\mathrm{EFs}}_{1 \tau}\right) / \hat{\alpha}_{\tau}
$$

and

$$
\begin{aligned}
\tilde{S}_{2 \tau}= & {\left[\hat{\psi}_{2 \tau}-\hat{\alpha}_{\tau} \hat{\delta}_{\tau} \overline{\operatorname{PerGrPop}}_{\tau}-\left(\hat{\beta}_{1 \tau} \overline{\operatorname{Dist}}_{1}^{\tau}+\hat{\beta}_{2 \tau} \overline{\operatorname{Dist}}_{2 \tau}\right)\right.} \\
& \left.+\left(\hat{\gamma}_{1 \tau} \overline{\mathrm{EFs}}_{1 \tau}+\hat{\gamma}_{2 \tau} \overline{\mathrm{EFs}}_{2 \tau}\right)\right] / \hat{\alpha}_{\tau},
\end{aligned}
$$

where the upper bars refer to the within-group variable means before and after the shock. The entry thresholds are then computed as $\tilde{S}_{2 \tau} / \tilde{S}_{1 \tau}=$ $\left(\tilde{S}_{2 \tau} / 2\right) / \tilde{S}_{1 \tau}$. The results of this exercise are presented in Table 7 . They show a substantial decrease in the minimum efficient scale for all market structures as a result of the abolishment of the Stamped Paper Tax. This confirms the prediction of the theoretical model that $S(\tau)>S(0)$, and it is consistent with 
TABLE 7

Changes in Competition due to the 1869 Tax Reform Act

\begin{tabular}{lcccc}
\hline \hline & $\tilde{S}_{1}$ & $\tilde{S}_{2}$ & $\tilde{S}_{2} / 2$ & $\tilde{S}_{2} / \tilde{S}_{1}$ \\
\hline Before 1869 tax reform & $34,319^{\mathrm{a}}$ & 93,013 & 46,507 & 1.355 \\
After 1869 tax reform & 5,350 & 27,698 & 13,849 & 2.589 \\
\hline${ }^{\text {a }}$ Since $\hat{\psi}_{1}<0$, we used $\hat{\psi}_{1}=0$. & & & &
\end{tabular}

recent findings for the United States that the scale of local production depends on the size of the city chosen. ${ }^{15}$ Table 7 also shows that as a result of the tax repeal, the profitability for each firm in multiple-firm markets almost doubled, rising from 1.36 to 2.59 , which confirms the theoretical prediction that $\delta \Pi / \delta \tau<0$.

\section{Conclusions}

In this paper, we designed a model of what happened in 1869 when the Netherlands repealed a newspaper stamp tax. Firms' variable costs declined, and new newspapers entered in response. The quasi experiment is used to draw inferences about newspapers' unobserved profits. The results show that the tax significantly lowered the population necessary to support a given market structure. We find that this particular relaxing of fiscal policy had a large impact on location choices of firms and the availability of new products.

The choice of where to start a new business depends on the growth in demand (population) of potential locations (markets, cities). In our analysis, we measured the growth of a decade. Our results have important policy implications. Cities aiming at prosperity compete for growth. Successful ones see more people choosing to live and work there. As a result, new businesses are founded. Fiscal incentives thus matter for business location choices. But perhaps more vital is the fact that thriving policy endears a town to people who are positively inclined toward working for future wealth.

The results presented in this paper are of general interest and can support any policy-related debate about the effects of taxation and entry limitation on profitability, market structures, location choices, development, and the growth of new industries and of emerging markets. Although of historical interest as well and holding true for a specific industry in a small open economy, the study's broader contribution is to a better understanding of the relation between fiscal policy and industrial organization. The 1869 tax reform act stimulated the profitability of firms, encouraged markets to grow, advanced competition, and boosted the development of the young and entrepreneurial industry of daily newspapers. Fiscal policy that suppresses the spread of knowledge to the general public is shown to undermine economic

${ }^{15}$ Holmes, Scale of Local Production and City Size, supra note 3. 
growth, development, and prosperity. After more than 150 years of freedom of speech, the topic of government intervention in the availability of information cannot be of more relevance than it is today, when the new multimedia communication opportunities challenge governments to face the increasing worldwide trade possibilities through internet exchange and to decide whether and how to develop fiscal policies for electronic trade for financing their own future prosperity.

\section{BIBLIOGRAPHY}

Berry, Steve. "Estimation of a Model of Entry in the Airline Industry." Econometrica 60 (1992): 889-917.

Besley, Timothy J. "Commodity Taxation and Imperfect Competition: A Note on the Effects of Entry." Journal of Public Economics 40 (1989): 359-67.

Bresnahan, Timothy F., and Reiss, Peter C. "Entry and Competition in Concentrated Markets." Journal of Political Economy 99 (1991): 9771009.

Carlton, Dennis W. "The Location and Employment Choices of New Firms: An Econometric Model with Discrete and Continuous Endogenous Variables." Review of Economics and Statistics 65 (1983): 440-49.

Central Bureau of Statistics Netherlands. "Publicaties Volkstellingen 1795-1971." CDROM. Amsterdam: Statistics Netherlands, Netherlands Institute for Scientific Information Services, 1999.

Dixit, Avinash K. "Entry and Exit Decisions under Uncertainty." Journal of Political Economy 97 (1989): 620-38.

Hemels, Joan M. H. J. Het Dagbladzegel in de Rariteitenkamer, 1869-1969. Rotterdam: Nijgh \& Van Ditmar Publishers, 1969.

Hemels, Joan M. H. J. De Pers onder het Juk van een Fiscale Druk. Amsterdam: Otto Cramwinckel Uitgeverij, 1992.

Holmes, Thomas J. "The Effect of State Policies on the Location of Manufacturing: Evidence from State Borders." Journal of Political Economy 106 (1998): 667-705.

Holmes, Thomas J. "Scale of Local Production and City Size." American Economic Review Papers and Proceedings 89 (1999): 317-20.

Jovanovic, Boyan, and MacDonald, Glenn M. "The Life Cycle of a Competitive Industry." Journal of Political Economy 102 (1994): 322-47.

Romer, Paul M. "New Goods, Old Theory, and the Welfare Costs of Trade Restrictions." Journal of Development Economics 43 (1994): 5-38.

Seade, Jesus K. "On the Effects of Entry.” Econometrica 48 (1980): 479-89. Wasylenko, Michael. "Empirical Evidence on Interregional Business Location Decisions and the Role of Fiscal Incentives in Economic Development." In Industry Location and Public Policy, edited by Henry H. Herzog, Jr., \& Alan M. Schlottmann, pp. 13-30. Knoxville: University of Tennessee Press, 1991. 